\title{
DALUWARSA DALAM KUHP DAN FIQH JINAYAH
}

\author{
Hanif Azhar \\ STAI Hasan Jufri Bawaen \\ hanif.azhar15@gmail.com
}

\begin{abstract}
This research is motivated by the prescription in the Indonesia Criminal Code (KUHP) which is became one of the causes of a prosecutor cannot prosecute and execute a sentence against a criminal offender. A concept that was initially unknown in Islamic criminal law (figh jinayah). The purpose of this study is to compare the concepts of prescription in the Indonesia Criminal Code and Islamic jurisprudence. This study uses a library research method with a comparative approach. The conclusion of this study is that the Indonesia Criminal Code the prescription applies to all criminal acts at the level of prosecution and the execution of penalties. On another side the prescription in Islamic criminal law can only be applied to takzir crime at the same level, namely prosecution and executing sentences.
\end{abstract}

Keywords: expiration, criminal law, Islamic jurisprudence

\begin{abstract}
Abstrak: penelitian ini dilatarbelakangi adanya daluwarsa dalam KUHP yang menjadi salah satu sebab seorang jaksa tidak dapat menuntut dan menjalankan hukuman terhadap pelaku tindak pidana. Sebuah konsep yang awalnya tidak dikenal dalam hukum pidana islam (fiqh jinayah). Tujuan penelitian ini adalah untuk membandingkan konsep daluwarsa dalam KUHP dan fiqh jinayah. Penelitian ini menggunakan metode penelitian pustaka dengan pendekatan perbandingan. Kesimpulan dari penelitian ini ialah bahwa dalam KUHP daluwarsa berlaku pada semua tindak pidana pada level penuntutan dan pelaksanaan hukuman sementara daluwarsa dalam hukum pidana islam hanya dapat diberlakukan pada jarimah takzir pada level yang sama, yaitu penuntutan dan menjalankan hukuman.
\end{abstract}

Kata kunci: daluwarsa, hukum pidana, figh jinayah

\section{Pendahuluan}

Kadaluwarsa merupakan salah satu sebab seorang jaksa tidak dapat mengajukan tuntutan atas nama negara terhadap seorang tersangka ke pengadilan. Begitu pula, dengan adanya daluwarsa, jaksa tidak dapat mengeksekusi suatu putusan pengadilan yang telah memiliki kekuatan hukum tetap terhadap seorang terhukum.

Dalam hukum pidana, dari seluruh proses peradilan, mulai dari tingkat penyelidikan, penyidikan, penuntutan, persidangan, putusan hingga eksekusi putusan, kadaluwarsa diberlakukan pada tahap penuntutan dan pelaksanaan hukuman. Sesuai ketentuan pasal 78 hingga 85 KUHP. 
Sementara di bidang hukum pidana islam (fiqh jinayah), ada istilah yang padan dengan daluwarsa, yaitu taqadum. Dari sini Penulis tertarik untuk meneliti sejauh mana kesepadanan dua istilah hukum ini. Penelitian ini menggunakan metode Penelitian Pustaka (Library Research) dengan Pendekatan Perbandingan (Comparative Approach). Sebagai mana dikatakan Peter Mahmud Marzuki, mengutip Van Apleddorn, perbandingan hukum merupakan suatu ilmu bantu bagi ilmu hukum dogmatik dalam arti bahwa untuk menimbang dan menilai aturan-aturan hukum dan putusan-putusan pengadilan yang ada dengan sistem hukum lain. ${ }^{1}$ Jadi penelitian ini bertujuan untuk membandingkan konsep daluwarsa dalam Hukum Pidana Konvensional yang digunakan di Indonesia, dalam hal ini KUHP dengan konsep daluwarsa (taqadum) yang digunakan dalam Hukum Pidana Islam (figh jinayah) yang tercantum di berbagai kitab fiqh maupun sumber-sumber buku hukum lainnya.

\section{Daluwarsa dalam KUHP}

Dalam terminologi ilmu hukum dikenal istilah daluwarsa. Menurut KBBI kata yang baku ialah kedaluwarsa. Dengan begitu penulisan lainnya (kadaluwarsa, kadaluarsa, kedaluarsa, apalagi daluarsa) sebenarnya tidak baku namun umum dipakai di masyarakat. ${ }^{2}$ Terutama dalam ilmu hukum, istilah yang populer ialah daluwarsa.

Dalam Kitab Undang-Undang Hukum Pidana (KUHP) yang merupakan terjemahan belaka dari Kitab Undang-Undang Hukum Pidana Hindia Belanda, Boergerlijk V an Straftrecht, istilah asal dari daluwarsa ialah Verjaring. ${ }^{3}$ Dalam bahasa Indonesia, daluwarsa dimaknai sebagai sudah lewat (habis) jangka waktunya (tentang tuntutan dan sebagainya) atau habis tempo. ${ }^{4}$ Menurut Michael R. Purba, daluwarsa ialah lewat waktu daluwarsa; hapus atau gugur karena lewatnya waktu; tidak dapat dituntut atau digugat lagi karena lewatnya waktu. ${ }^{5}$ Yang dimaksud daluwarsa dalam bahasa awam adalah "gugatan atau penuntutan atau upaya hukum lainnya sudah basi atau tidak masuk akal".6

Dalam KUHP dalawarsa ada dua macam: (1). Daluwarsa dalam penuntutan dan (2). Daluarsa dalam menjalankan hukuman.

\section{Daluarsa Penuntutan (Verjaring)}

Ketentuan tentang daluwarsa diatur dalam pasal 78-83 KUHP. Alasan gugurnya hak menuntut dalam KUHP ialah sebagai berikut :
a. Ne bis in idem (Pasal $76 \mathrm{KUHP}$ )
b. Matinya terdakwa (Pasal 77 KUHP)
c. Daluwarsa Hak Penuntutan (Pasal 78 KUHP)

\footnotetext{
${ }^{1}$ Peter Mahmud Marzuki, Penelitian Hukum (Kencana: Jakarta, 2007), 133.

2 https://kbbi.kemdikbud.go.id/entri/kedaluwarsa, diakses 16 November 2018

${ }^{3}$ Lihat Wirjono Prodjodikoro, Asas-Asas Hukum Pidana Di Indonesia (Jakarta: Eresco, 1981), 141.

${ }^{4}$ https://kbbi.kemdikbud.go.id/entri/kedaluwarsa, diakses 16 November 2018

${ }^{5}$ Michael R. Purba, Kamus Hukum Internasional Dan Indonesia (Jakarta: Widyatamma, 2009), 104.

${ }^{6}$ https://pojokhukumunas.wordpress.com/2015/05/07/daluwarsa-dalam-tindak-pidana/. Diakses 4 November 2018.
} 
d. Pembayaran denda maksimum terhadap pelanggaran yang diancam pidana denda (Pasal 82 KUHP)

e. Abolisi dan Amnesti (di luar KUHP) ${ }^{7}$

Pada bagian ini Penulis akan mengkaji alasan yang ke tiga, yaitu daluwarsa hak penuntutan.

Wirjono Prodjodikoro menjelaskan argumen mengapa suatu daluarwa dapat diberlakukan. Apabila suatu tindak pidana oleh karena beberapa hal tidak diselidiki dalam jangka waktu yang agak lama, maka masyarakat tidak begitu ingat lagi padanya, sehingga tidak begitu dirasakan perlunya dan manfaatnya menjatuhkan hukuman kepada si pelaku. Hal ini terutama berlaku bagi tindaktindak pidana yang ringan, yaitu seluruh jenis pelanggaran dan jenis kejahatan yang diancam dengan hukuman kurungan dan denda. Untuk kejahatan yang lebih dari itu, semakin lama perkara tidak diusut akan semakin sulit mendapatkan buktibukti yang cukup apabila terdakwa nantinya menyangkal kesalahannya. ${ }^{8}$

Dari sini jelas bahwa mayoritas tindak pidana yang dalam penuntutannya dapat diberlakukan daluwarsa terdiri dari kategori pelanggaran dan kejahatan yang diancam dengan hukuman kurungan dan denda saja. Beberapa saja yang tergolong tindak pidana beerat.

Pasal 78 ayat 1 KUHP menyebutkan waktu daluwarsa dan tindak pidana apa saja yang dapat hak penuntutannya gugur karena daluwarsa, yaitu: (1) sesudah 1 tabun, untuk semua pelanggaran dan kejahatan yang dilakukan dengan percetakan, (2) sesudah 6 tahun untuk kejahatan yang diancam dengan pidana denda, pidana kurungan, atau pidana penjara paling lama tiga tahun, (3) sesudah 12 tabun untuk kejahatan yang diancam dengan pidana penjara lebih dari tiga tahun, (4) sesudah 18 tahun mengenai kejahatan yang diancam dengan pidana mati atau pidana penjara seumur hidup.

Sementara pasal 78 ayat 2 menyebutkan apabila pelaku kejahatan itu umurnya belum 18 tahun, maka masa gugurnya waktu yang ditetapkan di atas dikurangi menjadi sepertiganya, yakni: (1) 4 bulan, untuk semua pelanggaran dan kejahatan yang dilakukan dengan percetakan, (2) 2 tahun untuk kejahatan yang diancam dengan pidana denda, pidana kurungan, atau pidana penjara paling lama tiga tahun, (3) 4 tahun untuk kejahatan yang diancam dengan pidana penjara lebih dari tiga tahun, (4) 6 tahun untuk kejahatan yang diancam dengan pidana mati atau pidana penjara seumur hidup.?

Kemudian kapan suatu masa daluwarsa itu dimulai atau terhitung sejak kapan masa daluwarsa itu berjalan?. Pasal 79 KUHP menjelaskan bahwa tenggang daluwarsa mulai berlaku pada hari sesudah perbuatan dilakukan. 1 hari sesudah

\footnotetext{
7 Andi Sofyan dan Nurul Aziza, Buku Ajar Hukum Pidana (Makassar: Pustaka Pena Press, 2016), 241. Lihat A. Ridwan Halim, Hukum Pidana Dalam Tanya Jawab (Jakarta: Galia: 1983), 166.

${ }^{8}$ Wirjono Prodjodikoro, Asas-Asas Hukum Pidana ..., 141

${ }^{9}$ R. Soegandi, KUHP dengan Penjelasannya (Surabaya: Usaha Nasional, 1980), 97-98.
}

\section{CENDEKIA : Jurnal Studi Keislaman}


peristiwa pidana itu terjadi. Kecuali dalam tindak pidana tertentu maka masa berlaku daluwarsa diatur sebagai berikut: (1). pemalsuan atau perusakan mata uang, berlaku pada hari sesudah barang yang dipalsu atau mata uang yang dirusak digunakan, (2). mengenai kejahatan dalam pasal-pasal 328, 329, 330, dan 333, dimulai pada hari sesudah orang yang langsung terkena oleh kejahatan dibebaskan atau meninggal dunia, (3). mengenai pelanggaran dalam pasal 556 sampai dengan pasal 558a, dimulai pada hari sesudah daftar-daftar yang memuat pelanggaranpelanggaran itu, menurut aturan-aturan umum yang menentukan bahwa registerregister catatan sipil harus dipindah ke kantor panitera suatu pengadilan, dipindah ke kantor tersebut.

Selain pemberlakuan daluwarsa dalam penuntutan, berlaku pula pencegahan dan penangguhan daluwarsa dalam penuntutan.

a. Pencegahan Daluwarsa (Stuiting Der Verjaring)

Yang dimaksud di sini ialah daluwarsa dihentikan (dicegah) sehingga tidak berjalan oleh karena suatu hal, tetapi pada waktu itu dimulai lagi tenggang daluwarsa baru. ${ }^{10}$

Menurut R. Soegandi, kata "pencegahan" di sini memiliki arti yang berbeda dengan kata "penangguhan". Sesudah pencegahan, dimulailah masa daluwarsa yang baru. Sementara sesudah penangguhan, berjalan lagi masa daluwarsa yang semula ditangguhkan itu (vide pasal 81). ${ }^{11}$

Pasal 80 KUHP menjelaskan: (1) Tiap-tiap tindakan penuntutan menghentikan daluwarsa, asal tindakan itu diketahui oleh orang yang dituntut, atau telah diberitahukan kepadanya menurut cara yang ditentukan dalam aturan-aturan umum, (2) Sesudah dihentikan, dimulai tenggang daluwarsa baru.

Yang dapat mencegah berlakunya masa daluwarsa ini ialah segala bentuk tindakan penuntutan yang diketahui orang yang dituntut atau menurut undang-undang telah diberitahukan kepadanya.

Tidak termasuk tindakan penuntutan ini ialah segala tindakan yang sifatnya mencari keterangan dan menyelidiki yang dilakukan jaksa atau polisi. Yang itu berarti tergolong tindakan penyelidikan atau penyidikan.

b. Penangguhan Daluwarsa (Schorsing Der Verjaring)

Pasal 81 KUHP menyatakan: penundaan penuntutan pidana berhubung dengan adanya perselisihan pra-yudisial, menunda daluwarsa

Hal ini terjadi apabila penuntutan pidana ditunda sementara karena masih adanya perselisihan hukum yang harus diputuskan lebih dahulu oleh kekuasaan lain, maka selama waktu penundaan itu masa daluwarsa tidak berjalan terus. Setelah perselisihan itu diputuskan, maka masa daluwarsa tadi berjalan lagi. ${ }^{12}$ Misalnya suatu penuntutan perkara perzinaan ditangguhkan

${ }^{10}$ Wirjono Prodjodikoro, Asas-Asas Hukum Pidana ..., 143.

11 R. Soegandi, KUHP dengan Penjelasannya ..., 100.

12 Ibid., 101. 
untuk menyelesaikan terlebih dahulu perkara perceraian suami-istri, yang salah satunya terlibat perzinaan yang sedang dituntut tadi. Perselisihan di sini biasa disebut perselisiban prejudicial.

\section{Daluwarsa Hak Menjalankan Hukuman}

Menurut Wirjono Prodjodikoro argumen hapusnya hak menjalankan hukuman sama dengan argumen hapusnya hak penuntutan kecuali dalam hal sulitnya pembuktian karena toh pelaku sudah divonis. ${ }^{13}$

Masa gugurnya hak menjalani hukuman ditetapkan lebih lama daripada masa gugurnya hak penuntutan pidana karena kesalahan terdakwa sudah pasti. Khusus untuk terpidana mati, hak menjalani hukuman mati tidak dapat gugur karena daluwarsa.. ${ }^{14}$

Daluwarsa menjalankan hukuman ini diatur dalam pasal 84 dan 85 KUHP. Pasal 84 menyatakan: (1) Kewenangan menjalankan pidana hapus karena daluwarsa, (2) Tenggang daluwarsa mengenai semua pelanggaran lamanya 2 tabun, mengenai kejahatan yang dilakukan dengan sarana percetakan lamanya 5 tahun, dan mengenai kejahatan-kejahatan lainnya lamanya sama dengan tenggang daluwarsa bagi penuntutan pidana, ditambah sepertiga, (3) Bagaimanapun juga, tenggang daluwarsa tidak boleh kurang dari lamanya pidana yang dijatuhkan, (4) Wewenang menjalankan pidana mati tidak daluwarsa.

Mengenai mulainya masa berlaku daluwarsa menjalankan hukuman pasal 85 KUHP menyatakan : (1) Tenggang daluwarsa mulai berlaku pada esok harinya setelah putusan hakim dapat dijalankan, (2) Jika seorang terpidana melarikan diri selama menjalani pidana, maka pada esok harinya setelah melarikan diri itu mulai berlaku tenggang daluwarsa baru. Jika suatu pelepasan bersyarat dicabut, maka pada esok harinya setelah pencabutan, mulai berlaku tenggang daluwarsa baru, (3) Tenggang daluwarsa tertuduh selama penjalanan pidana ditunda menurut perintah dalam suatu peraturan umum, dan juga selama terpidana dirampas kemerdekaannya, meskipun perampasan kemerdekaan itu berhubung dengan pemidanaan lain.

Sebagaimana daluwarsa dalam penuntutan, daluwarsa hak menjalankan hukuman juga berlaku pencegahan daluwarsa dan penangguhan daluwarsa.

a. Pencegahan Daluwarsa (Stuiting Der Verjaring)

Pasal 85 ayat 2 menyatakan: jika seorang terpidana melarikan diri selama menjalani pidana, maka pada esok harinya setelah melarikan diri itu mulai berlaku tenggang daluwarsa baru. Jika suatu pelepasan bersyarat dicabut, maka pada esok harinya setelah pencabutan, mulai berlaku tenggang daluwarsa baru.

b. Penangguhan Daluwarsa (Schorsing Der Verjaring)

13 Wirjono Prodjodikoro, Asas-Asas Hukum Pidana ..., 145.

14 R. Soegandi, KUHP dengan Penjelasannya ..., 103. 
Pasal 85 ayat 3 menyatakan: tenggang daluwarsa tertuduh selama penjalanan pidana ditunda menurut perintah dalam suatu peraturan umum, dan juga selama terpidana dirampas kemerdekaannya, meskipun perampasan kemerdekaan itu berhubung dengan pemidanaan lain.

Penangguhan daluwarsa ini terjadi misalnya apabila terhukum mengajukan grasi. Oleh karena pengajuan grasi ini, untuk sementara waktu hukuman tidak dijalankan.

\section{Daluwarsa Dalam Hukum Pidana Islam}

Daluwarsa dalam literatur figh jinayah dikenal dengan istilah taqaadum yang dibahas pada bab yang membicarakan tentang hukuman ('uqubaat) tepatnya pada sub bab tentang gugurnya hukuman (suqut al 'uqubab). Istilah lain inqidha' al 'uqubah (daluwarsa hukuman). Daluwarsa di sini menjadi salah satu sebab batal atau gugurnya hukuman. ${ }^{15}$ Dalam hukum pidana islam ada beberapa sebab yang dapat membatalkan hukuman. Sebab-sebab ini tidak berlaku umum untuk semua hukuman. Masingmasing sebab memiliki ketentuan tersendiri.

Abdul Qadir 'Audah menyebutkan tujuh sebab yang dapat menggugurkan hukuman, yaitu:

1. Pelaku meninggal dunia (mant al jaaniy)

2. Tidak adanya anggota tubuh yang dijatuhi hukum qisas (fawaat al mabal al qisas)

3. Pelaku bertaubat (tambah al janiy)

4. Perdamaian (sulh)

5. Pemaafan('afw)

6. Pewarisan qisas (irs al qisas)

7. Kadaluwarsa (taqaadum) ${ }^{16}$

Sementara Ahmad Fathi Bahansi menyebutkan lima, yaitu:

1. Mati (maut)

2. Pemaafan ('afw)

3. Perdamaian (sulh)

4. Taubat (taubab)

5. Kadaluwarsa (taqaadum $)^{17}$

Dari berbagai literatur Fiqh jinayah tidak ditemukan pembahasan daluwarsa selain dalam cakupan bab hukuman tersebut. Dengan demikian dalam Hukum Pidana Islam daluwarsa hanya ada pada pelaksanaan hukuman. Tidak pada penuntutan. Berbeda dengan pandangan KUHP yang berlaku di Indonesia. KUHP mengenal dua kondisi di mana daluwarsa diberlakukan yaitu pada tahap penuntutan

15 Ahmad Hanafi menyebutnya "pengurungan hukuman". Ahmad Hanafi, Asas-Asas Hukum Pidana Islam (Jakarta: Bulan Bintang 1967), 263.

16 Abdul Qadir Audah, At Tasyri' Al Jina'iy Al Islamiy, Juz 1 (Beirut: Dar al-Kutub al-Ilmiyah, 2011), 624.

${ }^{17}$ Ahmad Fathi Bahansi, Al Uqubah Fi Al Figh Al Islamiy (Bairut: Dar Al Syuruq, 1983), 223. 
dan tahap pelaksanaan hukuman. Oleh karena itu definisi daluwarsa yang diajukan Abdul Qadir Audah ialah sebagai berikut:

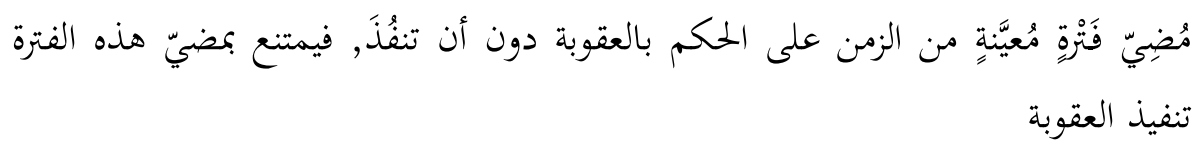

"lewatnya tenggang waktu tertentu atas vonis yang belum dieksekusi. Dengan lewatnya masa ini eksekusi hukuman menjadi tidak dapat dilaksanakan". ${ }^{18}$

Ahmad Hanafi mendefinisikan daluwarsa sebagai berlakunya suatu waktu tertentu atas keputusan adanya hukuman tanpa dilaksanakannya hukuman tersebut. Dengan berlakunya masa tersebut maka pelaksanaan hukuman menjadi terhalang. ${ }^{19}$ Artinya seorang pelaku tindak pidana yang telah diadili dan divonis oleh pengadilan namun oleh karena satu sebab hukuman itu tidak dapat dijalankan.

Dalam hal daluwarsa dapat membatalkan hukuman ini, fuqaha berbeda pendapat. Mayoritas fuqaha menolak adanya daluwarsa ini. Sementara sebagian fukaha lainnya berpendapat daluwarsa dapat membatalkan pelaksanaan hukuman meskipun hanya pada jarimah tertentu.

\section{Pendapat pertama}

Dikemukakan oleh mazhab imam Malik, Syafi'i, dan Ahmad. Pada pokoknya pendapat ini menyatakan bahwa hukuman yang belum dieksekusi tidak batal sebab daluwarsa. Begitu pula jarimah yang belum diajukan ke pengadilan (mubaakamab) tidak batal karena daluwarsa, kecuali untuk jarimah dan hukuman ta'zir dengan syarat ulil amri memandang itu perlu demi mewujudkan kemaslahatan umum.

Dasar pendapat ini ialah bahwa tidak ada satupun kaidah dan nash syariat yang menunjukkan bahwa hukuman atas jarimah budud, qisas dan diyat dapat batal sebab kadaluwarsa, sehingga ulil amri sama sekali tidak berhak untuk memberikan ampunan atau membatalkan hukuman atas berbagai jarimah ini. Dengan demikian tidak perlu ada kadaluwarsa.

Sementara hukuman takzir, kaidah umum penerapannya memang membolehkan adanya pembatalan hukuman sebab daluwarsa apabila ulil amri memiliki pertimbangan untuk itu demi kemaslahatan umum, baik terhadap jarimah maupun hukumannya. Ulil amri berhak memberikan pengampunan atas jarimah dan hukuman yang tergolong jarimah takzir. Bila ulil amri dapat memberikan pengampunan atas suatu hukuman lalu membatalkannya dengan segera, maka ulil amri juga dapat menentukan syarat agar pembatalan itu dapat dilaksanakan yaitu dengan adanya daluwarsa, dengan pertimbangan kemaslahatan umum atau menghindarkan mudharat.

18 Abdul Qadir Audah, At Tasyri' Al Jina'iy Al Islamiy ..., 630.

19 Ahmad Hanafi, Asas-Asas Hukum Pidana Islam ..., 266.

\section{6 | CENDEKIA : Jurnal Studi Keislaman}




\section{Pendapat kedua}

Pendapat ini dikemukakan oleh mazhab Abu Hanifah dan muridmuridnya (kecuali Zafar). Pendapat ini sepakat dengan pendapat pertama dalam hal bahwa kadaluwarsa dapat diterapkan pada jarimah ta'zir. Sementara untuk jarimah hudud, qisas dan diyat golongan kedua ini memiliki pendapat berbeda. Menurut pendapat ini daluwarsa dalam pelaksanaan hukuman dapat diberlakukan pada semua jarimah, baik itu jarimah hudud, qisas maupun diyat kecuali jarimah qadzaf (dari kategori jarimah hudud). Pemberlakuan daluwarsa pada semua jarimah budud, qisas maupun diyat selain qadzaf tadi dengan syarat pembuktian jarimah itu harus dengan kesaksian. Apabila pembuktiannya dengan pengakuan maka daluwarsa tidak dapat membatalkan hukuman.

Alasan pendapat ini ialah bahwa untuk diterimanya kesaksian, suatu jarimah tidak boleh kadaluwarsa. Ini berlaku pada semua jarimah hudud kecuali qadzaf, karena qadzaf merupakan delik aduan yang agar kasus hukumnya dapat diproses mensyaratkan adanya gugatan dari korban. Sebelum adanya gugatan korban, saksi tidak dapat bersaksi di depan sidang pengadilan. Sementara selain qadzf bukan merupakan delik aduan, sehingga agar perkaranya diproses oleh pengadilan tidak memerlukan adanya gugatan korban.

Ulama Hanafiah berargumen bahwa seorang saksi dapat memilih antara memberikan kesaksian dengan sukarela, berdasarkan firman Allah swt. wa aqim ussyahadata lillah (at-Thalaq: 2) atau menutupi (aib) peristiwa pidana itu, berdasarkan sebuah hadis "Barang siapa yang menutupi aib saudara sesama muslimnya maka Allah akan menutupi aibnya kelak di hari kiamat". Diamnya saksi hingga suatu peristiwa pidana menjadi lewat waktu/ daluwarsa mengindikasikan bahwa saksi memilih untuk tidak membuka aib orang lain. Namun bila saksi memberikan kesaksian setelah masa daluwarsa, mengindikasikan bahwa saksi memiliki motif lain yang cenderung negatif (misalnya dengki, dendam, dan sebagainya) terhadap pelaku. Dalam kasus ini kesaksiannya menjadi diragukan dan tidak dapat diterima. Kalangan ini memperkuat argumennya dengan satu riwayat dari Umar bin Khattab yang mengatakan "siapapun yang bersaksi atas kasus jarimah hudud sementara ketika kasus itu baru terjadi dia tidak memberikan kesaksian maka kesaksiannya itu timbul dari kebencian atau dendam [terhadap pelaku]. Dengan demikian kesaksiannya tidak dapat diterima". Ditegaskan pula bahwa tidak ada satupun sahabat yang menolak atau menentang pernyataan Umar ini sehingga dengan begitu dianggap telah terjadi ijma'. Dari hadis tersebut dapat disimpulkan bahwa pemberian kesaksian yang terlambat dapat menimbulkan tuduhan. Sementara kesaksian atas orang yang tertuduh dalam kondisi demikian tidak dibenarkan, sebagaimana sabda Nabi Muhammad saw "tidaklah diterima kesaksian seorang musuh dan orang yang dicurigai (zanin; muttaham).

Jika kesaksian atas orang yang dituduh itu ditolak maka logikanya kesaksian menjadi dapat diterima jika tidak ada tuduhan. Demikian pula jika 
misalnya saksi tidak dapat segera memberikan kesaksian dengan alasan jarak yang jauh [dari pengadilan] atau karena sakit. Namun jika tubmab itu tidak jelas, tidak tampak dan sulit untuk mengidentifikasinya dalam berbagai kondisi maka daluwarsa digunakan untuk menggantikan tuhmah ini, dan indikasi tubmah dapat diabaikan karena tidak ada alasan atas ada atau tidaknya tubmah tersebut. Dengan demikian, kesaksian tidak dapat diterima sebab daluwarsa meskipun tidak ada tubmah atau tidak dapat didatangkannya saksi.

Menurut Hanafiah, apabila kadaluwarsa dapat berlaku pada jarimah, maka sudah barang tentu dapat berlaku pula pada hukuman karena menurut kaidah mereka anna al-imdha' min al-qadha', eksekusi/ tanfidz itu menyempurnakan hukum. Segala hal yang wajib dilakukan dalam proses hukum menyebabkan wajib pula dilakukan ketika eksekusi/ pelaksanaan hukum. Sebaliknya, jika tidak ada kalaursa dalam proses hukum maka dalam eksekusinya juga tidak ada kadaluwarsa.

Abu Hanifah tidak memberikan batasan waktu terhadap masa daluwarsa. Pengaturan akan hal itu diserahkan kepada hakim dengan berbagai pertimbangan. Perbedaan alasan menyebabkan perbedaan penentuan batas waktu. Muhammad memberikan batasan dalurasa selama 6 bulan. Riwayat lain 1 bulan. Pendapat ini diikuti Muhammad dari Abu Hanifah dan Abu Yusuf. Jadi, ulil amri dapat menentukan batas waktu kadaluwarsa dan menolak menerima gugatan/ dakwaan setelah masa daluwarsa, apabila dalil atas suatu jarimah didasarkan atas kesaksian.

Kesimpulan dari pendapat resmi mazhab Hanafi dalam hal daluwarsa dapat membatalkan hukuman yaitu untuk daluwarsa dapat membatalkan sanksi takzir, apapun dasar pembuktian(dali) nya. Daluwarsa dapat pula membatalkan sanksi budud selain qadzaf apabila dasar pembuktiannya dengan kesaksian (syahadah). Apabila dengan pengakuan (igrar), menurut Abu Hanifah dan Abu Yusuf, maka daluwarsa tidak berlaku di sini, kecuali dalam sanksi minum khamar.

\section{Perbandingan Daluwarsa Dalam KUHP Dan Fiqh jinayah}

Berdasarkan jenis tindak pidananya, dalam KUHP daluwarsa berlaku pada semua jenis pelanggaran dan kejahatan. Dalam fiqh jinayah, hanya berlaku pada jarimah takzir.

Berdasarkan pemberlakuannya pada fase proses peradilan, daluwarsa dalam KUHP berlaku pada penuntutan dan menjalankan hukuman. Dalam fiqh jinayah, untuk jarimah takzir juga berlaku pada penuntutan dan menjalankan hukuman.

Berdasarkan mekanisme pengaturannya, daluwarsa dalam KUHP diatur cukup detail. Dalam fiqh jinayah, tidak diatur detail. Pengaturan selanjutnya diserahkan kepada kebijakan pemerintahan islam setempat.

\section{Kesimpulan}

Berdasarkan uraian di atas dapat disimpulkan bahwa daluwarsa dalam KUHP sebagai hukum positif yang berlaku di Indonesia dan daluwarsa dalam fiqh jinayah 
sebagai interpretasi terhadap hukum syariat memiliki perbedaan yang cukup prinsip. Daluwarsa dalam KUHP diberlakukan pada semua jenis pelanggaran dan kejahatan. Sementara dalam fiqh jinayah, menurut pendapat mayoritas, hanya dapat diberlakukan pada tindak pidana yang tergolong ke dalam jarimah takzir. Jarimah yang tergolong budud, qisas dan diat sebagai jarimah yang memiliki nash sharih yang tidak dapat diubah ketentuannya dimana tidak dalil yang mengatur tentang adanya daluwarsa. Sesuai prinsip dasarnya bahwa memang hanya jarimah takzir yang ketentuan mengenai jarimah dan hukumannya oleh syariat regulasinya tidak diatur jelas. Hal ini sebagai kebijakan syari' agar pemerintah islam lebih leluasa mengaturnya sendiri.

\section{Daftar Pustaka}

A. Ridwan Halim, Hukum Pidana Dalam Tanya Jawab (Jakarta: Galia: 1983)

Abdul Qadir Audah, At Tasyri' Al Jina'iy Al Islamiy, Juz 1, (Beirut: Dar al-Kutub alIlmiyah, 2011)

Ahmad Fathi Bahansi, Al Uqubah Fi Al Figh Al Islamiy (Bairut: Dar Al Syuruq, 1983) Ahmad Hanafi, Asas-Asas Hukum Pidana Islam (Jakarta: Bulan Bintang 1967)

Andi Sofyan dan Nurul Aziza, Buku Ajar Hukum Pidana (Makassar: Pustaka Pena Press, 2016)

Michael R. Purba, Kamus Hukum Internasional Dan Indonesia (Jakarta: Widyatamma, 2009), 104.

Peter Mahmud Marzuki, Penelitian Hukum (Kencana: Jakarta, 2007)

R. Soegandi, KUHP dengan Penjelasannya (Surabaya: Usaha Nasional, 1980)

Wirjono Prodjodikoro, Asas-Asas Hukum Pidana Di Indonesia (Jakarta: Eresco, 1981)

https://kbbi.kemdikbud.go.id/entri/kedaluwarsa, diakses 16 November 2018

https://pojokhukumunas.wordpress.com/2015/05/07/daluwarsa-dalam-tindakpidana/. Diakses 4 November 2018. 